\title{
Current-fed Step-up DC/DC Converter for Fuel Cell Applications with Active Overvoltage Clamping
}

\author{
Aleksandrs Andreiciks, Riga Technical University, Ingars Steiks, Riga Technical University, \\ Oskars Krievs, Riga Technical University
}

\begin{abstract}
In order to use hydrogen fuel cells in domestic applications either as main power supply or backup source, their low DC output voltage has to be matched to the level and frequency of the utility grid AC voltage. Such power converter systems usually consist of a DC-DC converter and a DC-AC inverter. A double inductor step-up push-pull converter is investigated in this paper, presenting simulation and experimental results for passive and active overvoltage clamping. The prototype of the investigated converter is elaborated for 1200 $W$ power to match the rated power of the proton exchange membrane (PEM) fuel cell located in hydrogen fuel cell research laboratory.
\end{abstract}

Keywords: fuel cell system, high frequency power converters, ZVS converters

\section{INTRODUCTION}

The research of the hydrogen energy has gained a growing interest in the recent years. The hydrogen fuel cells are fully ecological, taking into account that heat and water are the only by-products, which are excreted into the environment [1]. In order to utilize the electrical energy, produced by hydrogen fuel cells, characterized by slow dynamic response, low output voltage and large voltage variations, various static power electronic converters are researched widely.

The fuel cells used as main power supply or backup source in domestic application need to be connected to the grid. Such power converter systems usually consist of a DC-DC converter and a DC-AC converter. Because of the comparatively high input and output voltage difference most frequently converters with high frequency transformer are acknowledged as the optimal solution for the DC-DC stage [1]-[4]. There are many known transformer isolated dc-dc converter topologies, which could be suitable to perform the necessary voltage boost from the fuel cell voltage level to the inverter dc link voltage. Such converters are the full-bridge, half-bridge, the flyback, the forward and the push-pull basic topologies, as well as a number of their derived topologies [5], [6] These can be divided into two groups - voltage fed converters and current fed converters. In this paper a current fed topology is preferred, since it is characterized by low input current ripple, which is more appropriate for proton exchange membrane fuel cells modules [3],[4].

A double inductor boost push-pull converter investigated in the paper, presenting simulation and experimental results. The converter is elaborated for $1200 \mathrm{~W}$ power, since such is the rated power of the proton exchange membrane (PEM) fuel cell in hydrogen fuel cell research laboratory of Riga Technical University.

\section{THE SELECTED CONVERTER TOPOLOGY}

Considering the necessity of high voltage boosting function with low input current ripple, the most appropriate converters are current fed full-bridge and push-pull configurations. Since the converter efficiency can be considerably improved by reducing the count of the primary switches and implementing a transformer of a simple structure (without split windings), a double inductor push-pull converter (DIC) was selected and analyzed in this paper (Fig.1.).

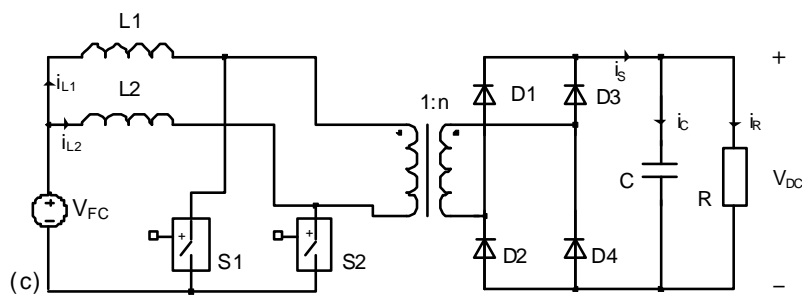

Fig. 1. Current fed double inductor push-pull converter topology.

The hard switching converters have a drawback of voltage overshoots at turn-off due to the energy stored in the parasitic inductances. These voltage spikes are not only dangerous to the transistors but they substantially increase the switching losses.

There are two basic ways to protect the transistor switches from being damaged by the overvoltage. The first is using transistors with blocking voltage ratings that exceed these stresses. This, however, results in poor utilization of the transistors, since on state resistance of the MOSFET transistors increases dramatically with increased blocking voltage. The other way is to limit the stresses within safe levels using snubber circuits. The highest voltage spikes across the switches in the topology under consideration appear at turn-off, when the overvoltage occurs due to the transformer leakage inductance. Therefore two clamping circuit topologies together with conventional RC snubber circuits were implemented to limit the voltage during turn-off - a passive and an active voltage clamping circuit. 


\section{OVERVOLTAGE PROTECTION OF THE SWITCHES}

\section{A. Passive Voltage Clamping}

The energy from the leakage inductance of transformer is dissipated on passive clamping circuit, which consists of two clamping diodes, clamping capacitor and clamping resistor. Fig. 2. shows the schematic of DIC converter with passive clamping circuit. The capacitor of the clamp circuit has to ensure that the clamp circuit overtakes the energy from the transformer leakage inductance, without increasing voltage of the switches beyond safe values and can be calculated from the following equation:

$$
C_{\text {clamp }}=2 \cdot L_{l k}\left(I_{F C}+\Delta I_{F C}\right)^{2} /\left(V_{\text {clamp }}^{2}-V_{\text {norm }}^{2}\right),
$$

where: $C_{\text {clamp }}$ is the capacitance of the clamp capacitor, $L_{l k}$ is the leakage inductance of the transformer, $V_{\text {clamp }}$ is the maximum, but $V_{\text {norm }}$ - normal voltage of the clamp capacitor. The clamp resistor, on the other hand, has to be calculated to discharge the clamp capacitor to its normal voltage and dissipate the energy collected from the leakage inductance, according to:

$$
R_{C}=\left(V_{n o r m}-V_{F C}\right)^{2} / P_{l k},
$$

where

$$
P_{l k}=\frac{1}{2} \cdot L_{l k} \cdot\left(\frac{I_{F C}+\Delta I_{F C}}{2}\right)^{2} \cdot 2 f_{S}
$$

is the power to be dissipated in the clamp resistor.

Unfortunately such passive clamping circuit can be optimized only for one operation point, so the maximum load condition was chosen for calculation, since it is the worst case.

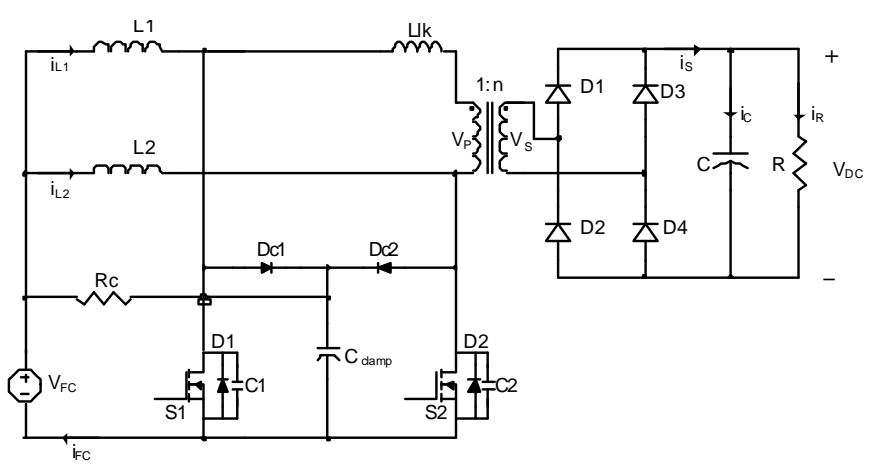

Fig. 2. Curent-fed DIC Converter with Passive Clamping Circuit.

\section{B. Active Voltage Clamping}

A DIC converter with active clamping circuit, which uses controlled switches instead of the diodes and without clamping resistor is shown on Fig. 3. In this case, the energy from the leakage inductance is not dissipated on the clamping resistance but transferred to the output. The active clamping circuit can improve the efficiency of the converter, as it does not dissipate the leakage inductor energy on a resistance but feeds it to the transformer primary. The theoretical converter operation waveforms are shown in Fig. 4.

Active clamping circuit has some very important advantages over passive clamping circuit, for example, it is able to operate at the zero voltage switching (ZVS) mode both at turn-on and turn-off for all switches and simple to implement as it contains only a capacitor and two transistors controlled in anti-phase to the main switches. The basis of the operation of the presented clamping circuit is the resonant phenomena between the leakage inductance of the transformer $\left(L_{l k}\right)$ and the clamping capacitor $\left(C_{\text {clamp }}\right)$.

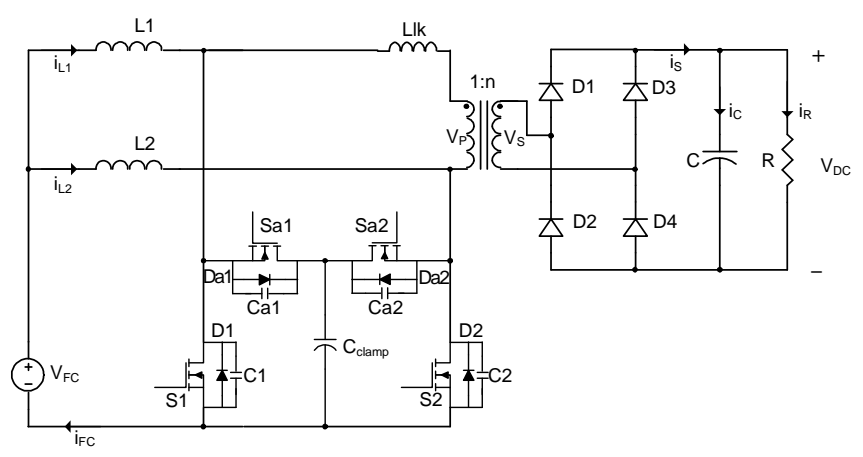

Fig. 3. Curent-fed DIC Converter with Active Clamping Circuit.

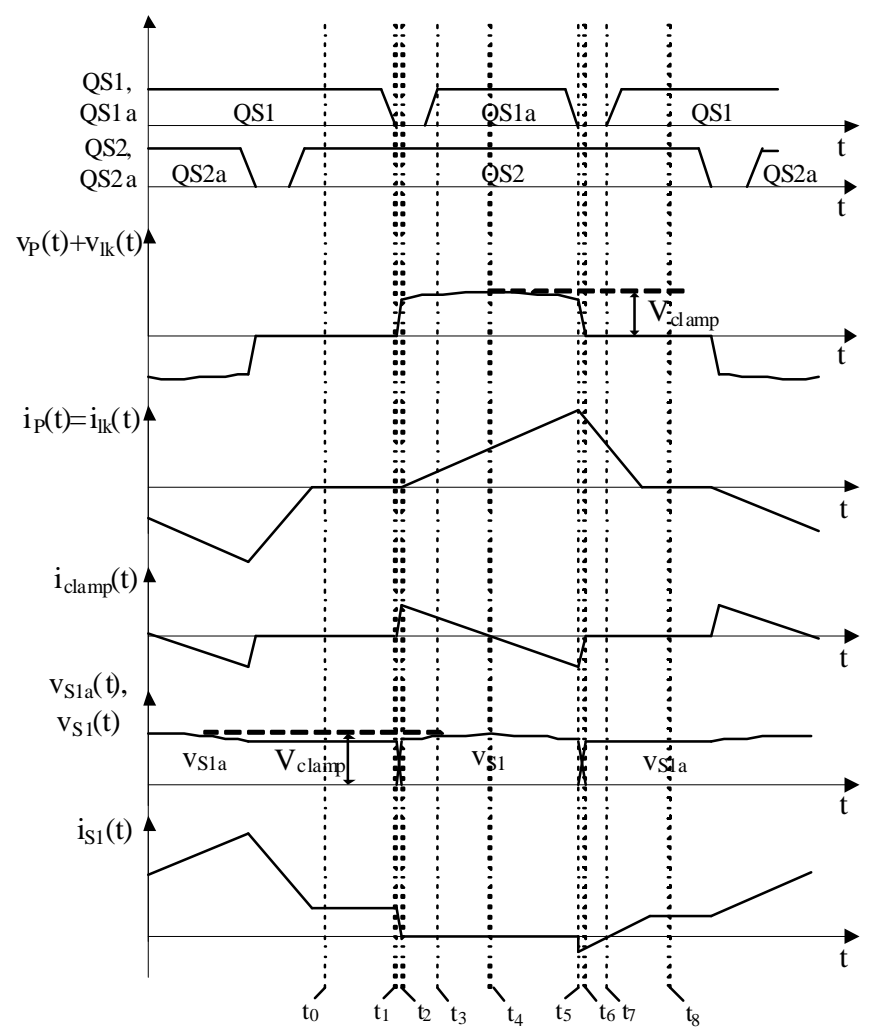

Fig. 4. The converter waveforms according to the operation of the clamping circuit.

The value of $C_{\text {clamp }}$ should be set so that one half of the resonant period formed by Cclamp and $L_{l k}$ exceeds the 
maximum turn-off time of the main switches. [4] The clamping capacitor value is

$$
C_{\text {clamp }}>T_{s}^{2}(1-D)^{2} / \pi^{2} \cdot L_{l k}
$$

To achieve ZVS mode for the main switch, it must be turned on after turn-off the auxiliary switch. This delay should be selected to be less than one quarter of the resonant period formed by $L_{l k}$ and $C_{1}$ capacitor [4]

$$
T_{M 1-M 1 a}=\sqrt{L_{l k} \cdot C_{1}} \cdot \pi / 2
$$

where the value for $C_{1}$ has been taken from the datasheet of the chosen switch. The maximum time delay between turning off the main switch and turning on the auxiliary, using the calculated minimum value for the clamping capacitor can be considered by

$$
T_{M 1-M 1 a}=\sqrt{L_{l k} \cdot C_{\text {clamp }}} \cdot \pi / 2
$$

\section{Simulation OF THE DIC CONVERTER}

The simulation of the DIC converter was done using LTspice simulation tool. Since a steady operation point was to be examined, the FC was modeled by a constant voltage source. The core losses of the inductances were neglected. The transformer was modeled as an ideal transformer introducing the leakage inductance in series. The power MOSFET transistor switches (IXFN73N30) and active clamping MOSFET transistors (IRF740) were modeled using SPICE models provided by the manufacturers. The control circuit was realized using a field-programmable gate array (FPGA) Spartan 3E board from Digilent.

The operation conditions of the simulation are adjusted to the rated parameters of the converter. Active load with a small filter capacitor of $10 \mu \mathrm{F}$ was considered. The value of leakage inductance $(\mathrm{Llk}=4,8 \mu \mathrm{H})$ was obtained experimentally, by measuring the transformers mutual and self-inductances. It can also be noted, that the converter operates as desired, providing $400 \mathrm{~V}$ output voltage at rated input and load conditions and that the transistor voltage does not exceed the maximum allowed voltage of main power transistor $300 \mathrm{~V}$ and maximum allowed current 73A.

\section{A. Passive Voltage Clamping}

The schematic of DIC converter with passive clamping circuit in LTspice environment and simulation results for the topology with passive clamping are presented in Fig.5. and Fig.6. The results show that using the clamping capacitor the voltage overshoot on the MOSFET is limited to a safe value.
The above simulations can be used to determine the RMS current of the clamping diodes.

\section{B. Active Voltage Clamping}

The schematic of DIC converter with active clamping circuit in LTspice environment and simulation results for the active clamping topology are presented in Fig. 7. and Fig. 8. It can be noted that the shape of the auxiliary switch current is determined by the resonant circuit formed by the $L_{l k}$ and $C_{\text {clamp. }}$.

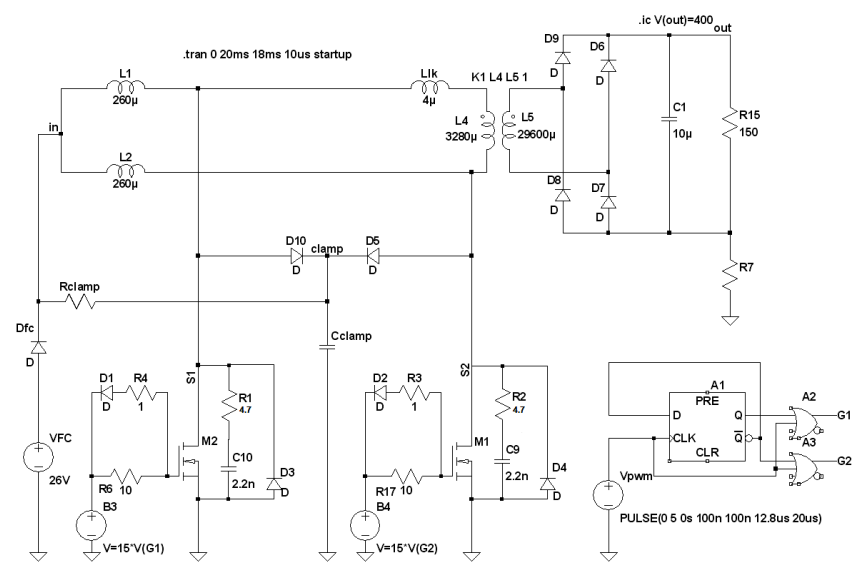

Fig. 5. DIC Converter Schematics with Passive Clamping Circuit in LTSpice environment.

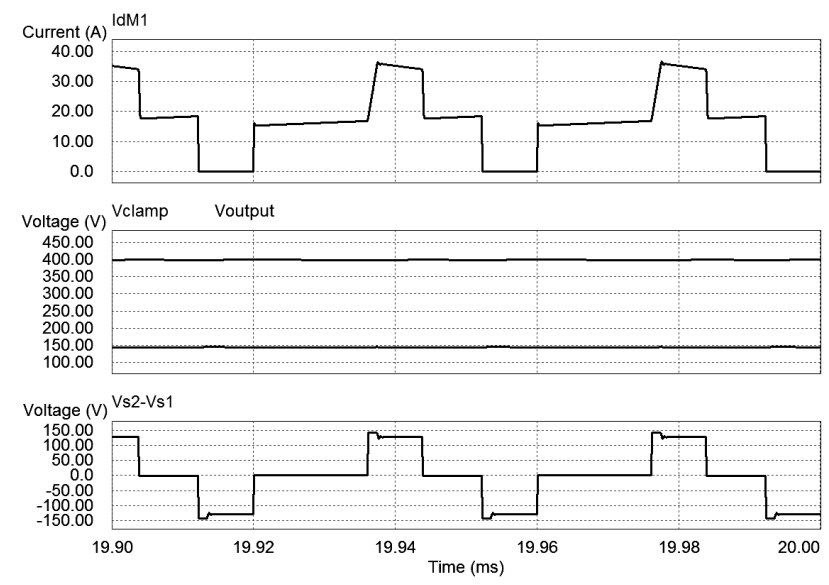

Fig. 6. Simulated waveforms of the DIC converter with passive clamping circuit: from the top - current through transistor M1, output voltage, voltage of the clamp capacitor, transformer primary voltage.

It can also be noted, that the converter operates as desired, providing $400 \mathrm{~V}$ output voltage at rated input and load conditions. 


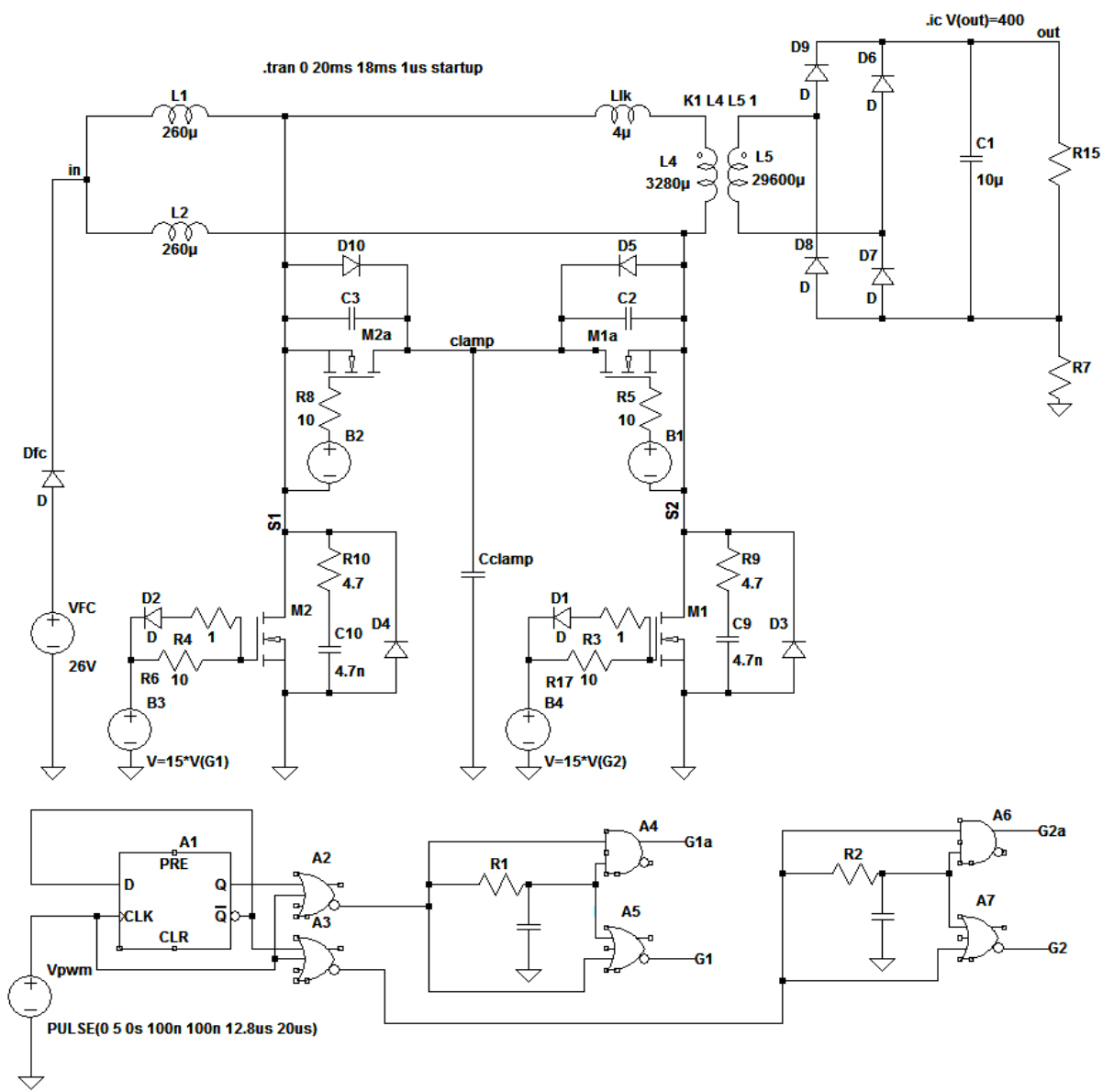

Fig. 7. DIC Converter schematics with Active Clamping Circuit in LTSpice environment.
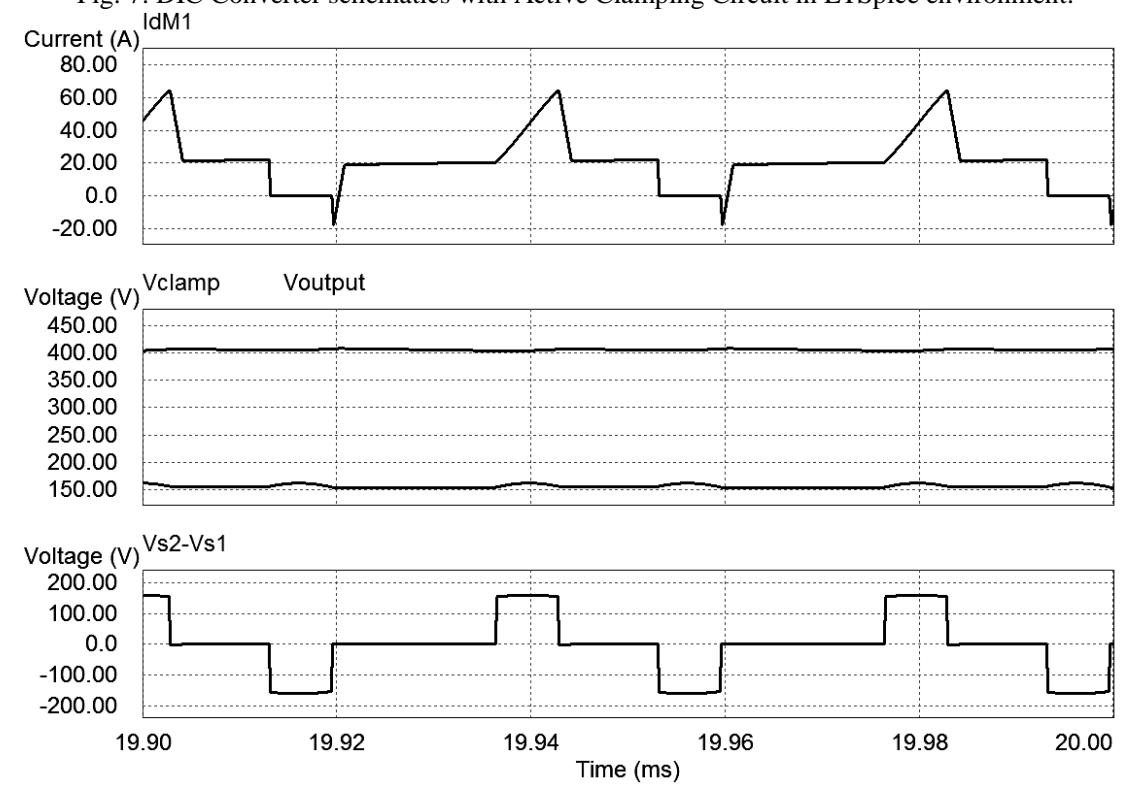

Fig. 8. Simulated waveforms of the DIC converter with active clamping circuit: from the top - current through transistor M1, output voltage, voltage of the clamp capacitor, transformer primary voltage. 


\section{V.EXPERIMENTAL RESULTS}

Experimental testing of active clamping DIC converter was carried out as well. The testing was performed using Ballard Nexa PEM fuel cell module with nominal power $1,2 \mathrm{~kW}$ and connecting the DIC converter to a resistive load. Measurements of the input current, input voltage and load voltage and current were done. Then the efficiency of the converter was calculated. The efficiency of the DIC converter with the passive clamping circuit is approximately $88 \%$ and with the active clamping circuit is $93 \%$ (Table I.).

TABLE I

THE MEASURED QuANTITIES

\begin{tabular}{|l|l|l|}
\hline \multirow{2}{*}{ Parameter } & \multicolumn{2}{|l|}{ Measurements } \\
\cline { 2 - 3 } & $\begin{array}{l}\text { Passive clamp } \\
\sim 730 \mathrm{~W}\end{array}$ & $\begin{array}{l}\text { Active clamp } \\
\sim 760 \mathrm{~W}\end{array}$ \\
\hline Vin & $23.3 \mathrm{~V}$ & $26.7 \mathrm{~V}$ \\
\hline Vout & $411 \mathrm{~V}$ & $336 \mathrm{~V}$ \\
\hline Iin & $35.8 \mathrm{~A}$ & $28.73 \mathrm{~A}$ \\
\hline Iout & $1.78 \mathrm{~A}$ & $2.12 \mathrm{~A}$ \\
\hline efficiency & $88 \%$ & $93 \%$ \\
\hline
\end{tabular}

\section{A. Passive Voltage Clamping}

Basing on equations (1) and (2), the estimated resistance of the clamping resistor was $670 \Omega$ and the capacitance of the clamping capacitor $6 \mu \mathrm{F}$. In case the resistor is too small and the clamping capacitor discharges too fast, there is the possibility to decrease the voltage on the clamping capacitor below the transformer primary voltage, causing the clamping diodes to work as a rectifier of the primary voltage which reduces the overall efficiency of the converter. In parallel with the power transistors, RC snubber circuits were implemented composed of $2.2 \mathrm{nF}$ polyester film capacitors and $4,7 \Omega 5 \mathrm{~W}$ resistors.

Experimental waveforms of the DIC converter with the passive clamping circuit are shown in Fig. 9. The tests were performed below the rated power of the converter approximately $730 \mathrm{~W}$ at the output, at full load conditions the turn-off voltage overshoots are close to the maximum transistor blocking voltage $(300 \mathrm{~V})$ signifying that further optimization of the clam and snubber circuits needs to be carried out if passive clamping circuit is used.

The input current and voltage of the DIC converter prototype are shown on Fig.10. As evident, the input current ripple is $\pm 1.5 \mathrm{~A}$ (less than $5 \%$ of the average value of the current), which is satisfactory.

\section{B. Active Voltage Clamping}

Faster diodes (better turn-on and turn-off characteristics than integrated diodes in transistors) and $2.2 \mathrm{nF}$ capacitors were added in parallel with active clamping transistors. In parallel with the power transistors, RC snubber circuits were implemented composed of $4,7 \mathrm{nF}$ polyester film capacitors and $4.7 \Omega 5 \mathrm{~W}$ resistors. Basing on equation (4) the capacitance of the clamping capacitor was $3,3 \mu \mathrm{F}$.

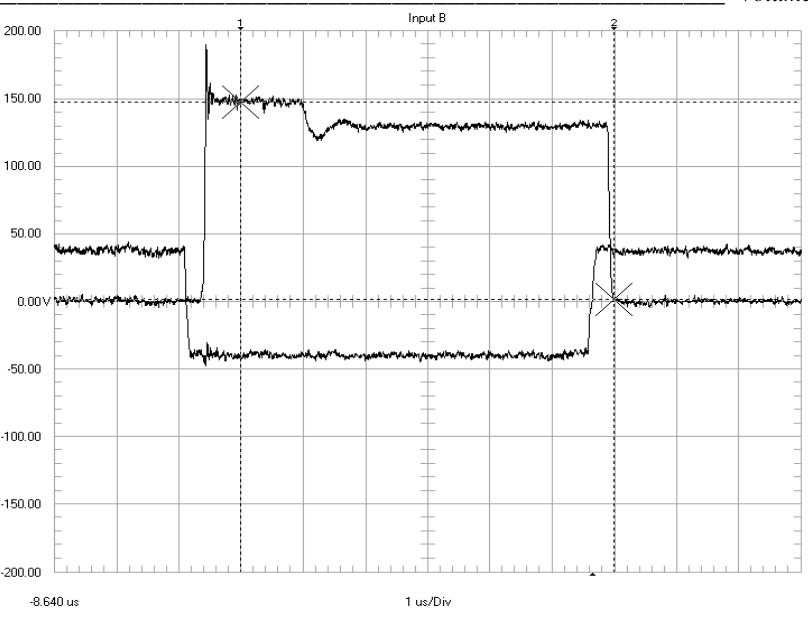

Fig. 9. Experimental waveforms of the DIC converter with the optimized board layout - from the top: control voltage, voltage across one power transistor.

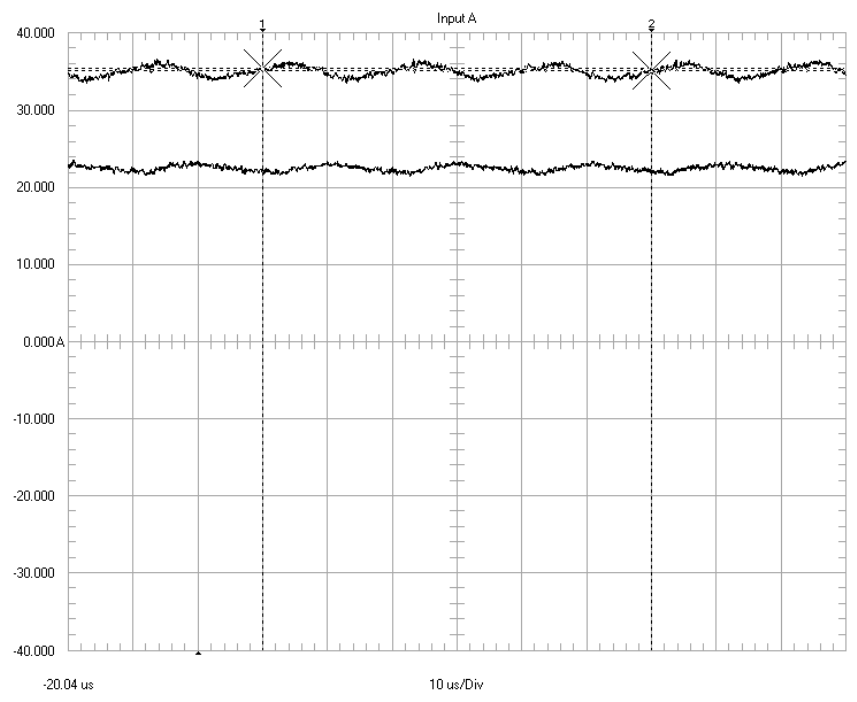

Fig. 10. Experimental waveforms of the DIC converter with the optimized board layout - from the top: input current, input voltage.

Experimental waveforms of the DIC converter with the active clamping circuit are shown in Fig.11. Active clamping and power transistor control voltage are shown in Fig. 12. It was possible to test converter at full load as there was no primary switch overvoltage problems.

\section{ConClusions}

The power converter necessary in order to use the hydrogen fuel cell as a main power supply or backup source in domestic applications usually consists of a step-up DC/DC stage and a DC/AC inverter stage. As an efficient solution for the DC/DC stage - a double inductor push pull converter with active voltage clamping circuit is analyzed in this paper presenting simulation and experimental results.

It was acknowledged that the DIC converter with active clamping circuit performs well and the efficiency of the converter is $93 \%$. The efficiency could be further increased 


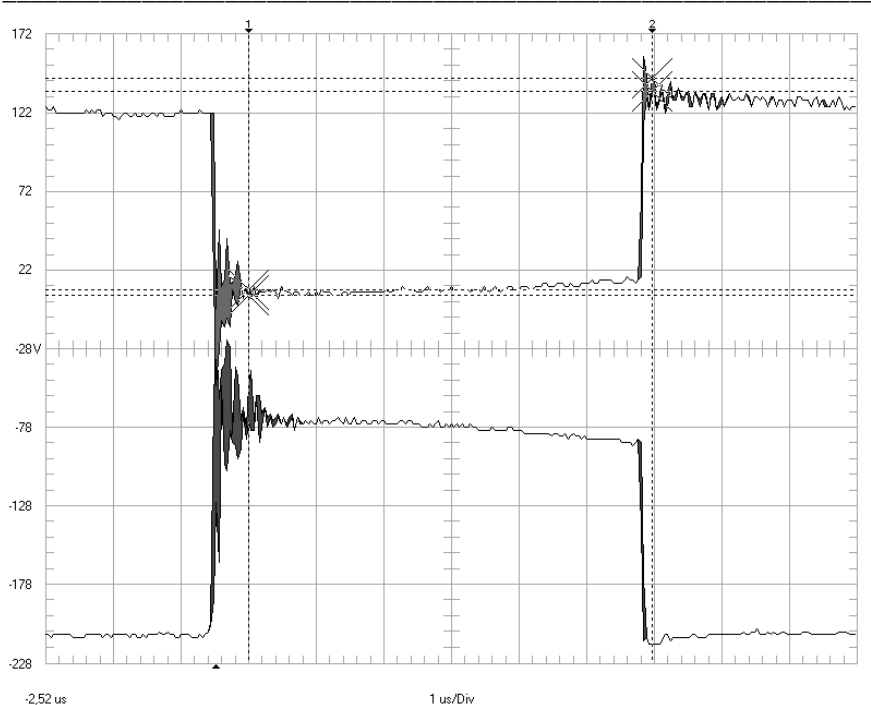

Fig. 11. .Experimental waveforms of the DIC converter with the active clamping - from the top: voltage across one active clamping tranzistor, voltage across one power transistor.

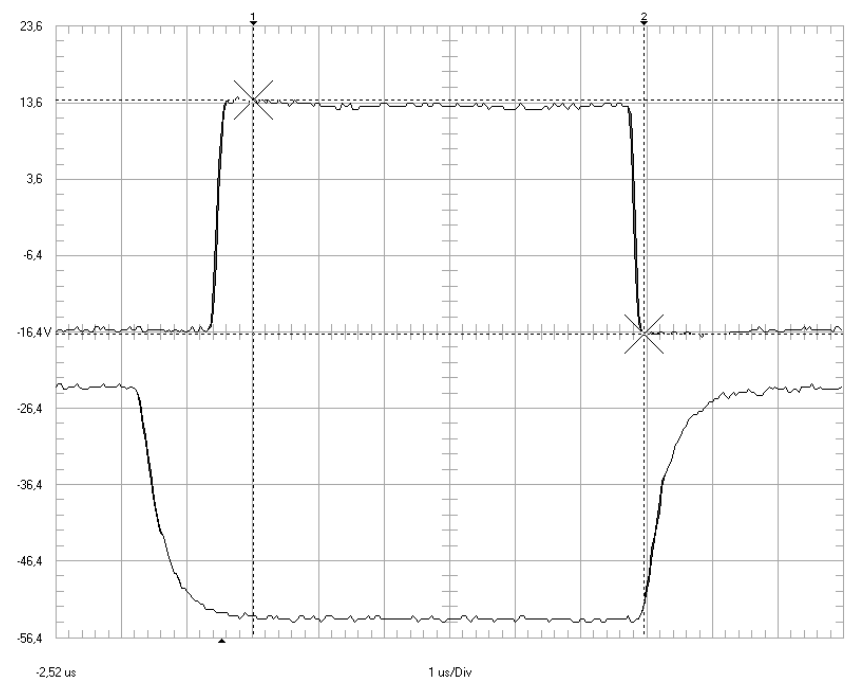

Fig. 12. .Experimental waveforms of the DIC converter with the active clamping - from the top: control voltage of the one active clamping transistor, control voltage of the one power transistor.

basically in two ways: by decreasing the resistance of the converter's primary circuit components or by reducing the primary current, which can be achieved by connecting two or more identical converters in parallel.

The ripple of the input current of the experimental prototype is below $\pm 5 \%$ of the mean value, which is within acceptable limits for the fuel cell.

The elaborated prototype of double inductor push-pull DC/DC converter with active clamping circuit can be used as a background for further work on clamp circuit optimization and elaboration of closed loop current control system.

\section{ACKNOWLEDGMENT}

This work has been supported by the European Social Fund within the project ,Support for the implementation of doctoral studies at Riga Technical University".

\section{REFERENCES}

[1] EGG Services Parsons Inc., "Fuel cell handbook (6th edition)", United States Department of Energy, USA, November 2002.

2] G. Gentile, S. Meo, F. Esposito, "Comparison Among Different Topologies of DC-DC Converter for Fuel-Cell-Based Inverter System", EPE-PEMC2004, Riga, Latvia, September 2004.

[3] W. Choi, P.N. Enjeti, J. W. Howze, G. Joung, "An experimental evaluation of the effects of ripple current generated by the power conditioning stage on a proton exchange membrane fuel cell stack", Journal of Materials Engineering and Performance, New York, USA, Vol. 13. pp.3257-264, 2004.

[4] S. De Caro, A. Testa, D. Triolo, M. Cacciato, A. Consoli, "Low Input Current Ripple Converters for Fuel Cell Power Units// in Proc. Hard Switching Converters and Control EPE 2005. - Germany, 2005.

[5] N. Mohan, T. Undeland, W.P. Robbins, "Power Electronics. Converters, Applications and Design", John Wiley \& Sons, ISBN:0-471-22693-9, 2003.

[6] R.W. Erickson, D. Maksimovic, "Fundamentals of Power Electronics", Chapman \& Hall, ISBN 0-7923-7270-0, 2001.

[7] J.T. Kim, B.K. Lee, T.W. Lee, S.J. Jang, S.S. Kim, C.Y. Won, “An Active Clamping Current-Fed Half-Bridge Converter for Fuel-Cell Generation Systems", 35th Annual IEEE Power Electronics Specialists Conference, Aachen, Germany, 2004.

[8] F.J. Nome, I. Barbi, "A ZVS Clamping Mode - Current-Fed Push-pull DC-DC Converter”, IEEE, 1998.

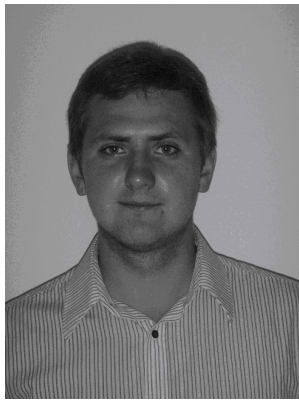

Alexander Andreiciks was born in Riga, Latvia, in 1985. He received the B.sc.ing. and M.sc.ing degree at Riga Technical University, Riga, Latvia in 2006 and 2008, respectively. Currently he is working towards a PH.D. degree in Riga Technical University, Riga, Latvia

$\mathrm{He}$ is currently an scientific assistant in the Institute of Industrial Electronics and Electrical Engineering, Riga Technical University. His main field of interest is the design and optimization of power electronic circuits for renewable energy systems.

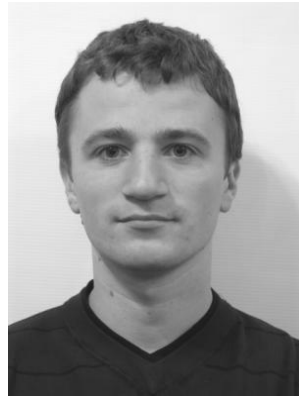

Ingars Steiks received the B.sc.ing. and M.sc.ing. degree from the Faculty of Power and Electrical Engineering, Riga Technical University, Riga, Latvia, in 2003 and in 2005 accordingly.

Since 2006, he has been a Researcher in the Institute of Industrial Electronics and Electrical Engineering, Riga Technical University. His main research interests include modular multilevel power converter applications for fuel cells.

Mr. Steiks is a Student Member of the IEEE Industrial Electronics Society since 2006.

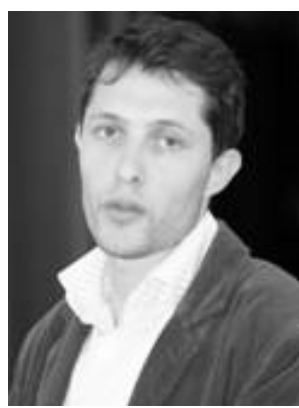

DC/DC converters.
Oskars Krievs has received Bachelor's (2001), Master's (2003) and Doctor's (2007) degrees in the field of electrical engineering at the Faculty of Power and Electrical Engineering of Riga Technical University.

O. Krievs has been working in Riga Technical University since 2001 and currently is in the positions of assistant professor and leading researcher at the Department of Power and Electrical Engineering of Riga Technical University. His main research fields include active power filters, frequency converters and 